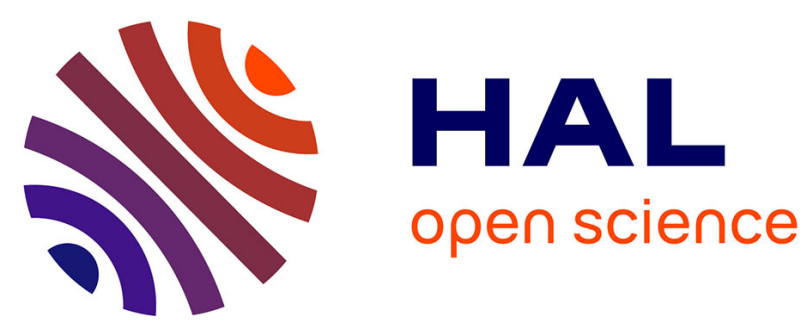

\title{
Synthesis, characterization and crystal structures of two new platinum complexes with planar chiral 1,2-disubstituted ferrocenes containing phosphine and thioether donor groups
}

\author{
Raluca Malacea, Eric Manoury, Jean-Claude Daran, Rinaldo Poli
}

\section{To cite this version:}

Raluca Malacea, Eric Manoury, Jean-Claude Daran, Rinaldo Poli. Synthesis, characterization and crystal structures of two new platinum complexes with planar chiral 1,2-disubstituted ferrocenes containing phosphine and thioether donor groups. Journal of Molecular Structure, 2008, 890 (1-3), pp.249-254. 10.1016/j.molstruc.2008.04.007 . hal-03191489

\author{
HAL Id: hal-03191489 \\ https://hal.science/hal-03191489
}

Submitted on 7 Apr 2021

HAL is a multi-disciplinary open access archive for the deposit and dissemination of scientific research documents, whether they are published or not. The documents may come from teaching and research institutions in France or abroad, or from public or private research centers.
L'archive ouverte pluridisciplinaire HAL, est destinée au dépôt et à la diffusion de documents scientifiques de niveau recherche, publiés ou non, émanant des établissements d'enseignement et de recherche français ou étrangers, des laboratoires publics ou privés. 


\section{Synthesis, characterization and crystal structures of two new platinum complexes with planar chiral 1,2- disubstituted ferrocenes containing phosphine and thioether donor groups ${ }^{1}$}

Raluca Malacea, Eric Manoury, * Jean-Claude Daran and Rinaldo Poli*

Laboratoire de Chimie de Coordination, UPR CNRS 8241 liée par convention à l'Université

Paul Sabatier et à l'Institut National Polytechnique de Toulouse, 205 Route de Narbonne,

31077 Toulouse Cedex, France.

E-mails: $\underline{\text { manoury@1cc-toulouse.fr }}$ and $\underline{\text { Rinaldo.Poli@1cc-toulouse.fr }}$

Proofs to:

Rinaldo Poli

Tel: $+33-561333173$

Fax: $+33-561553003$

E-mail: Rinaldo.Poli@1cc-toulouse.fr

${ }^{1}$ Dedicated to the memory of F. Albert Cotton, a caring mentor and a good friend. 


\begin{abstract}
The platinum complex [1,2-Fc( $\left.\left.\mathrm{PPh}_{2}\right)\left(\mathrm{CH}_{2} \mathrm{SPh}\right)\right] \mathrm{PtCl}_{2} \mathbf{1}$ has been transformed into [1,2$\left.\mathrm{Fc}\left(\mathrm{PPh}_{2}\right)\left(\mathrm{CH}_{2} \mathrm{SPh}\right)\right] \mathrm{PtCl}\left(\mathrm{SnCl}_{3}\right) 2$ as a single isomer, in high yields, by reaction with $\mathrm{SnCl}_{2}$. The $\mathrm{SnCl}_{2}$ reagent inserts regioselectively in the $\mathrm{Pt}-\mathrm{Cl}$ bond trans to the sulphur atom, while the sulphur atom configuration is fully controlled by the planar chirality of the P,S ligand. Complex 1 has also been efficiently reduced in the presence of diphenylacetylene to a single isomer of $\left[1,2-\mathrm{Fc}\left(\mathrm{PPh}_{2}\right)\left(\mathrm{CH}_{2} \mathrm{SPh}\right)\right] \mathrm{Pt}(\mathrm{PhCCPh})$, 5, where the central chirality on sulphur is again maintained. In compound 5, the central $\mathrm{CC}$ bond of the diphenylacetylene moiety acquires a strong double bond character. The structures of complexes $\mathbf{1}$ and $\mathbf{5}$ have been determined by X-ray diffraction on monocrystals. To the best of our knowledge, this study presents the first example of fully characterised $\mathrm{L}_{2} \mathrm{PtCl}\left(\mathrm{SnCl}_{3}\right)$ and $\mathrm{L}_{2} \mathrm{Pt}(\mathrm{PhCCPh})$ complexes, $\mathrm{L}_{2}$ being a $\mathrm{P}, \mathrm{S}$ ligand.
\end{abstract}

Keywords: Platinum, ferrocene chemistry, phosphine ligands, thioether ligands, planar chirality 


\section{Introduction}

Since its discovery by Pauson ${ }^{1}$ and the first studies, which actively involved F. A. Cotton, ${ }^{2}$ ferrocene has been used in fields of chemistry, like electrochemistry ${ }^{3}$, material science $^{4}$, synthesis, and catalysis, particularly enantioselective catalysis because of their stability, easy introduction of planar chirality ${ }^{5}$ and special electronic and stereoproperties of the ferrocene skeleton. Amongst the chiral ferrocene-based ligands, enantiopure 1,2disubstituted ferrocene derivatives, especially ferrocenyl-diphosphine ligands, played a major role. $^{6}$ Important examples (see Scheme 1) are P,P ligands like TRAP ${ }^{7}$, Josiphos ${ }^{8}$, and particularlqy the industrially important Xyliphos ${ }^{9}$, Taniaphos ${ }^{10}$ and Walphos-type ${ }^{11}$ ligands, $\mathrm{P}, \mathrm{N}$ ligands ${ }^{12}$ especially phosphine-oxazolines like, for instance $\mathrm{DIPOF}^{13}$, and more recently $\mathrm{P}, \mathrm{S}$ ligands like Fesulphos ${ }^{14}$.

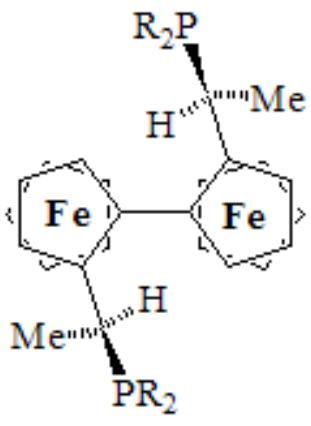

TRAP

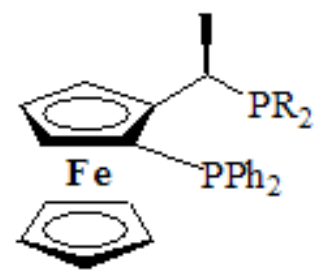

Josiphos : $\mathrm{R}=\mathrm{Cy}$

Xyliphos: $\mathrm{R}=3,5-\mathrm{Me}_{2} \mathrm{C}_{6} \mathrm{H}_{3}$

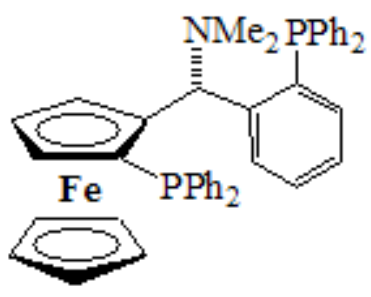

Taniaphos

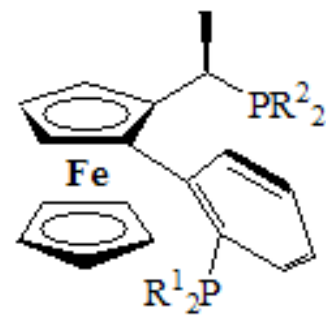

Walphos

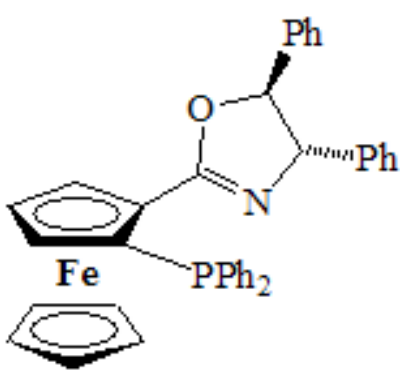

DIPOF

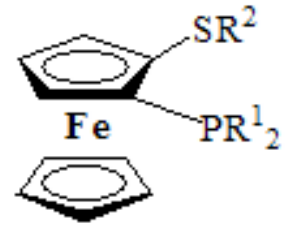

Fesulphos

Scheme 1 
We have recently developed new chiral ferrocenyl (P,S) ligands with general formula $\mathrm{CpFe}\left\{1,2-\mathrm{C}_{5} \mathrm{H}_{3}\left(\mathrm{PPh}_{2}\right)\left(\mathrm{CH}_{2} \mathrm{SR}\right)\right\}^{15}$, characterized by having only planar chirality, in both racemic and enantiomerically pure forms ( $\mathrm{R}$ or $\mathrm{S}$ configuration $)^{16}$ and briefly reported on their coordination chemistry ${ }^{17}$. These ligands could be successfully applied to a few asymmetric catalytic reactions, namely palladium-catalyzed allylic substitution ${ }^{15,18}$ and iridium-catalyzed ketone hydrogenation ${ }^{19}$. We have shown that the sulphur atom configuration is fully controlled by the planar chirality of the ligand. ${ }^{17}$ This is expected to be crucial in the transmission of chiral information to the catalytic metal. In this paper we report on the synthesis and characterization of two new platinum complexes containing the $(\mathrm{P}, \mathrm{S})$ ligand [1,2-Fc $\left.\left(\mathrm{PPh}_{2}\right)\left(\mathrm{CH}_{2} \mathrm{SPh}\right)\right]$, which are potentially interesting for catalytic applications. One interesting aspect of this work is the stereochemical integrity shown by the sulfur donor atom while other metal-ligand bonds are implicated in different chemical transformations.

\section{Results and Discussion}

Several systems associating a platinum dichloride complex and tin dichloride have been used in the hydroformylation reaction of alkenes ${ }^{20}$ and, particularly, in its asymmetric version. $^{21,22}$ In these systems, platinum complexes bearing one chloro ligand and one trichlorotin ligand are considered to be important catalytic intermediates. Therefore, we decided to study the reaction of the platinum complex $\left[1,2-\mathrm{Fc}\left(\mathrm{PPh}_{2}\right)\left(\mathrm{CH}_{2} \mathrm{SPh}\right)\right] \mathrm{PtCl}_{2}, \mathbf{1}$, with $\mathrm{SnCl}_{2}$.

The reaction of complex 1 with one equivalent of $\mathrm{SnCl}_{2} \cdot \mathrm{H}_{2} \mathrm{O}$ in refluxing toluene yields a red solid, 2, in good yields (90\%) after one hour. This solid was first studied by NMR in $\mathrm{CDCl}_{3}$. Only one signal at $\delta 1.21$, different from that of the starting complex $1(\delta-0.8)$, was detected in the ${ }^{31} \mathrm{P}$ NMR. This signal has two satellites corresponding to the Pt-P coupling $\left(\mathrm{J}_{\mathrm{PPt}}=3517 \mathrm{~Hz}\right)$ and two additional satellites corresponding to the Sn-P coupling $\left(\mathrm{J}_{\mathrm{PSn}}=183\right.$ 
$\mathrm{Hz}$ ). This confirms the presence of tin in the product. In principle, two stereoisomers $\mathbf{a}$ and $\mathbf{b}$, corresponding respectively to the insertion of $\mathrm{SnCl}_{2}$ into the $\mathrm{Pt}-\mathrm{Cl}$ bonds trans to $\mathrm{S}$ and trans to $\mathrm{P}$, would be expected (see Scheme 2), but the ${ }^{31} \mathrm{P}$ NMR data show that only one compound is present. In addition, since the sulphur atom has central chirality, two different diastereoisomers for each geometric (cis/trans) isomer could exist in combination with the ferrocene planar chirality. The same phenomenon could take place for the starting material $\mathbf{1}$, but only one diastereoisomer (with the sulphur substituent anti and the sulphur lone pair syn relative to the $\mathrm{Fe}$ atom) was found for this compound. ${ }^{17 \mathrm{c}}$ Thus, the formation of only one product from the single diastereoisomer of the starting compound shows that the reaction is not only regioselective with respect to the reactive $\mathrm{Pt}-\mathrm{Cl}$ bond but also diastereoselective with respect to the sulphur configuration (either $100 \%$ retention or $100 \%$ inversion).

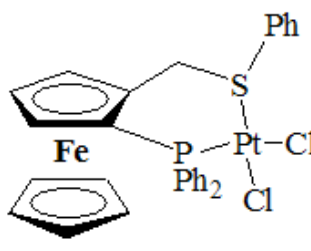

1

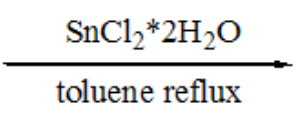

toluene reflux

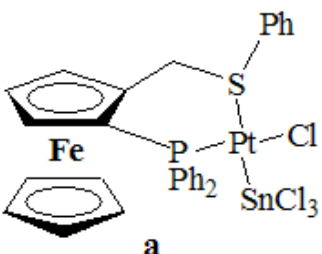

a

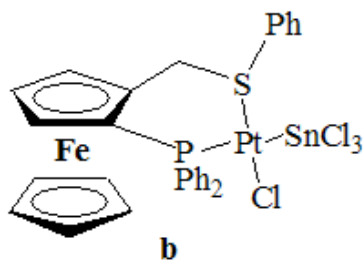

2

Scheme 2

For the similar complexes cis- $\left(\mathrm{PR}_{3}\right)_{2} \mathrm{PtCl}\left(\mathrm{SnCl}_{3}\right)$, it has been shown that the $\mathrm{Pt}-\mathrm{P}$ coupling constants are greater for the $\mathrm{P}$ atom trans to $\mathrm{Cl}(3090-4910 \mathrm{~Hz})$ than for the $\mathrm{P}$ atom trans to $\mathrm{SnCl}_{3}(2520-4110 \mathrm{~Hz}){ }^{22,23}$ For compound 2, however, the Pt-P coupling constant $\left(\mathrm{J}_{\mathrm{PPt}}=3517 \mathrm{~Hz}\right)$ is inside both ranges and does not allow an unambiguous structural assignment. On the other hand, the Sn-P coupling constant is more diagnostic because its value for cis- $\left(\mathrm{PR}_{3}\right)_{2} \mathrm{PtCl}\left(\mathrm{SnCl}_{3}\right)$ is very different when $\mathrm{P}$ atom is trans to $\mathrm{Cl}(78-235 \mathrm{~Hz})$ or trans to $\mathrm{SnCl}_{3}(373-5600 \mathrm{~Hz}){ }^{22,23}$ When compared with these literature precedents, the value 
for $2\left(\mathrm{~J}_{\mathrm{PSn}}=183 \mathrm{~Hz}\right)$ strongly suggests that the phosphorus atom is in trans of the chlorine atom, namely that isomer $\mathbf{a}$ is the reaction product.

The ${ }^{195} \mathrm{Pt}$ chemical shift ${ }^{24}$ for compound $2(\delta-4273)$ is, as expected, slightly downfield from those observed for the corresponding complexes bearing two phosphine ligands $(\delta-4710$ to -4910$)^{24 a, 25,22 c}$ as already observed within the cis- $\mathrm{PtCl}_{2} \mathrm{~L}_{2}$ family. ${ }^{\text {Erreur } ! \text { Signet non défini.c }}$ The chemical shift of $\mathbf{2}$ is upfield relative to the corresponding dichloro complex $\mathbf{1}(\delta=-4093$ ppm), as found in similar pairs. ${ }^{24 a}$ The ${ }^{13} \mathrm{C}$ NMR and ${ }^{1} \mathrm{H}$ NMR data also confirm that only one compound is present in solution. To the best of our knowledge, this study is the first characterization of a $\mathrm{L}_{2} \mathrm{PtClSnCl} l_{3}$ complex, with $\mathrm{L}_{2}$ beeing a $\mathrm{P}, \mathrm{S}$ ligand.

Single crystals of $\mathbf{2}$ were obtained by slow diffusion of pentane in a dichloromethane solution. The structure obtained by $\mathrm{X}$ ray diffraction (Figure 1) shows a square planar geometry around the platinum atom with the $\mathrm{SnCl}_{3}$ group in trans to the sulphur atom. The (R/S)-2 molecule is to the best of our knowledge the first (phosphine-thioether)- $\mathrm{PtCl}\left(\mathrm{SnCl}_{3}\right)$ complex characterized by X-ray analysis. The asymmetric unit contains two nearly identical molecules with the same $\left(R_{F c}, R_{s}\right)$ or $\left(S_{F c}, S_{s}\right)$ configuration. The phenyl substituent on the sulphur atom is oriented anti relative to the Fe atom, i.e. the observed diastereomer is the same as that of the starting compound, meaning that the the sulphur configuration of the (R/S)-1 precursor is preserved during the reaction with $\mathrm{SnCl}_{2}$. The PtPSClSn fragment of each independent molecule shows the expected planar coordination geometry around the central Pt atom as evidenced from: (i) the sum of the four intra- and interligand cis angles, found equal to $360.5^{\circ}\left(359.9^{\circ}\right)$, and (ii) from the angle between the normal to the two planes defined by the PtPS and PtClSn fragments which is equal to $3.38(4)^{\circ}\left(7.9(1)^{\circ}\right)$ thus deviating only a little from the ideal value of $0^{\circ}$ required for an undistorted planar geometry. The geometry within the square plane compares well with related structures containing the $\operatorname{PtCl}\left(\mathrm{SnCl}_{3}\right)$ fragment as shown in Table 1. It is worth noting that the $\mathrm{Pt}-\mathrm{Sn}$ bond is 
significantly shorter in (R/S)-2 than in complexes $3^{22 \mathrm{c}}$ and $\mathbf{4}^{23 \mathrm{~b}}$ where the $\mathrm{SnCl}_{3}$ group is trans with respect to a phosphorus atom. This result was expected, because the trans effect of the thioether group is weaker than that of a phosphine. The angles around the platinum atom are similar for the three complexes.

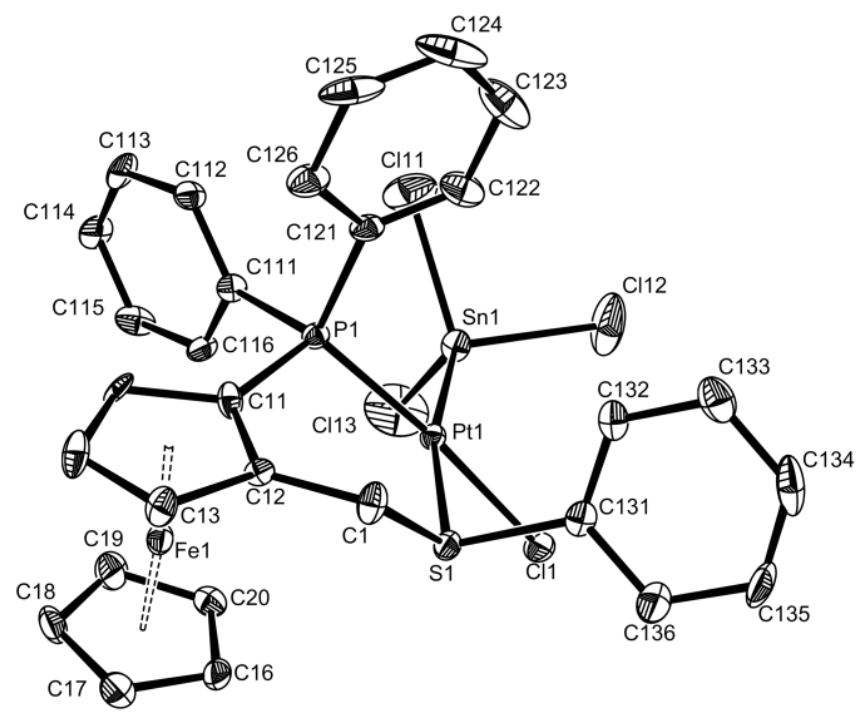

Figure 1. Molecular view of one of the two crystallographically independent molecules of (R/S)-2 with the atom-labelling scheme. Displacement ellipsoids are drawn at the $30 \%$ probability level. $\mathrm{H}$ atoms have been omitted for clarity.<smiles>C[C@H]1C[C@@H](C)[P@@]([SeH])[P@@](Cl)P1[PbH2]</smiles>

3

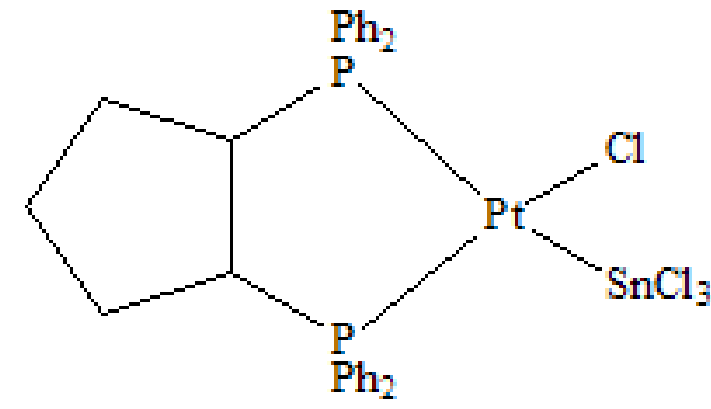

4

Scheme 3 
Table 1. Comparison of bond distances $(\AA)$ and angles (deg) for complexes $2,{ }^{\text {a }} \mathbf{3}$ and $\mathbf{4}$

\begin{tabular}{|c|c|c|c|c|}
\hline & \multicolumn{2}{|c|}{2} & 3 & 4 \\
\hline $\mathbf{P t}-\mathbf{P}($ trans to $\mathrm{Cl})$ & $2.223(2)$ & $2.235(2)$ & 2.234 & $2.275(5)$ \\
\hline $\mathbf{P t}-\mathbf{X}(\text { trans } \text { to } \mathrm{Sn})^{\mathrm{b}}$ & $2.357(2)$ & $2.347(2)$ & 2.309 & $2.281(5)$ \\
\hline $\mathbf{P t}-\mathbf{S n}$ & $2.5331(6)$ & $2.5312(6)$ & 2.582 & $2.572(2)$ \\
\hline $\mathbf{P t}-\mathbf{C l}$ & $2.350(2)$ & $2.334(2)$ & 2.347 & $2.283(9)$ \\
\hline $\mathbf{P}-\mathbf{P t}-\mathbf{X}^{\mathrm{b}}$ & $95.85(7)$ & $94.88(7)$ & 93.83 & $87.0(2)$ \\
\hline $\mathbf{C l}-\mathbf{P t}-\mathbf{S n}$ & $83.98(5)$ & $82.71(5)$ & 81.55 & $85.2(3)$ \\
\hline Reference & \multicolumn{2}{|c|}{ This work } & $22 \mathrm{c}$ & $23 b$ \\
\hline
\end{tabular}

${ }^{\mathrm{a}}$ The parameters for the two independent molecules are listed in separate columns. ${ }^{\mathrm{b}} \mathrm{X}=\mathrm{S}$ for 2; $\mathrm{P}$ for 3 and 4.

In order to obtain $\mathrm{Pt}^{0}$ complexes, which are potential catalyst for several reactions ${ }^{26,27}$, the reactivity of complex $\mathbf{1}$ was tested with diphenylacetylene in presence of sodium tris(methoxy)borohydride as a reducing agent (see scheme 4), following a method described by Glueck et $a .^{27}$ for the synthesis of a trans-stilbene $\operatorname{Pt}(0)$ complex (scheme 4$)$. The expected reactivity is the reduction of platinum(II) to $\mathrm{Pt}^{0}$, the coordination sphere being completed by diphenylacetylene acting as L ligand. The reaction was carried out in THF room temperature for two hours. A brown compound, [1,2- $\left.\mathrm{Fc}\left(\mathrm{PPh}_{2}\right)\left(\mathrm{CH}_{2} \mathrm{SPh}\right)\right] \mathrm{Pt}(\mathrm{PhC} \equiv \mathrm{CPh})(\mathbf{5})$, was obtained in $89 \%$ yield.

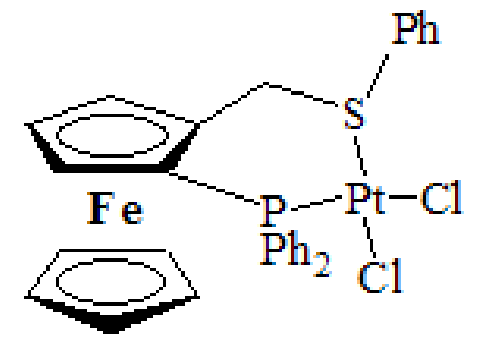

1
$\mathrm{PhC} \equiv \mathrm{CPh}$

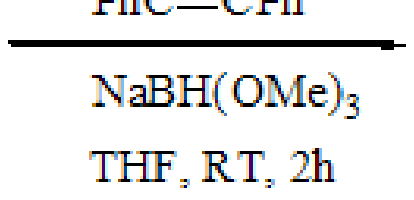

THF, RT, $2 h$

Scheme 4

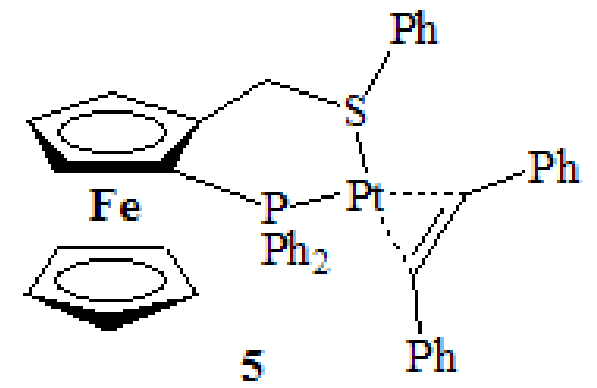


The ${ }^{31} \mathrm{P}$ NMR spectrum of 5 shows one single singlet at $\delta 12.6$ with two satellites corresponding to the platinum-phosphorus coupling $\left(\mathrm{J}_{\mathrm{PPt}}=3758 \mathrm{~Hz}\right)$ different from that of the starting complex $1\left(\delta=-0.8 \mathrm{ppm}, \mathrm{J}_{\mathrm{PPt}}=3608 \mathrm{~Hz}\right)$ indicating the presence of only one compound. Similarly, the ${ }^{1} \mathrm{H}$ NMR spectrum presents only one singlet for a 1,2-disubstitued ferrocene and also a more complex signal corresponding to 25 aromatic protons (15 from the P,S ligand and 10 from diphenylacetylene). The structure proposed in Scheme 4 is also supported by the ${ }^{13} \mathrm{C}$ NMR data, which clearly show the presence of a dissymmetrically coordinated diphenylacetylene. In particular, the signals corresponding to the 2 carbons of the $\mathrm{C} \equiv \mathrm{C}$ bond are found at $127.1 \mathrm{ppm}$ and $126.5 \mathrm{ppm}$.

Single crystals of (R/S)-5 were obtained by slow diffusion of pentane in a dichloromethane solution. The structure obtained by X ray diffraction is presented in Figure 2 . Because the synthesis of this complex was made starting from a racemic mixture of $\mathbf{1}$, both enantiomers of $\mathbf{5}$ are present in the crystal. The asymmetric unit of compound (R/S)-5, like that of compound $\mathbf{2}$ discussed above, contains two crystallographically independent molecules, both containing the same relative configuration for the two elements of chirality, $\left(R_{F c}, R_{s}\right)$ or $\left(S_{F c}, S_{s}\right)$. Once again, the chemical transformation from $\mathbf{1}$ to $\mathbf{5}$ does not change the initial configuration of the sulphur atom, because the $\mathrm{Ph}$ substituent on the $\mathrm{S}$ atom is oriented anti to the Fe atom in both compounds. The $\mathrm{X}$ ray structure shows that the phenyl acetylene is $\eta^{2}$ bonded to the platinum, as proposed by the NMR data. Thus, $\mathbf{5}$ is a platinum(0) ferrocenylphosphine-thioether complex. To the best of our knowledge, no other phosphinethioether $\mathrm{Pt}^{0}$ complex has previously been described in the literature. We can compare the structural data of complex 5 with those of bis(phosphine) $\mathrm{Pt}^{0}$ complexes containing diphenylacetylene, $\mathbf{6}^{28}, \mathbf{9}^{29}, \mathbf{1 0 - 1 2}{ }^{30}$ and 1,4-diphenylbutadiyne, $\mathbf{7}^{31}, \mathbf{8}^{32}$ (scheme 5). The principal structural data for these complexes are collected in Table 2. The C1-C2 distance 
corresponds to the $\mathrm{C}-\mathrm{C}$ bond that is $\eta^{2}$ bonded to the platinum atom. Positions $\boldsymbol{\alpha}$ and $\boldsymbol{\beta}$ correspond to the atoms directly bonded to $\mathrm{C} 1$ and $\mathrm{C} 2$.

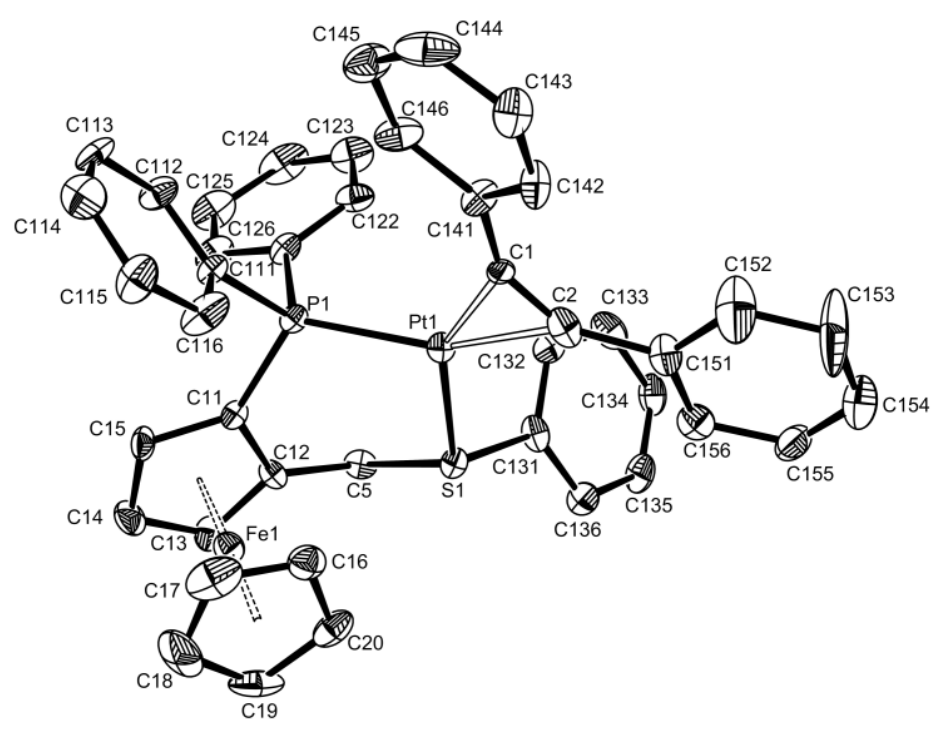

Figure 2. Molecular view of one of the two crystallographically independent molecules of (R/S)-5 with the atom-labelling scheme. Displacement ellipsoids are drawn at the $30 \%$ probability level. $\mathrm{H}$ atoms have been omitted for clarity.

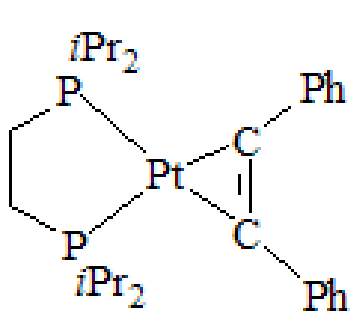

6<smiles>P[Pb]P1C([Pb])=C1C=CPc1ccccc1</smiles>

$\mathrm{Ph}$

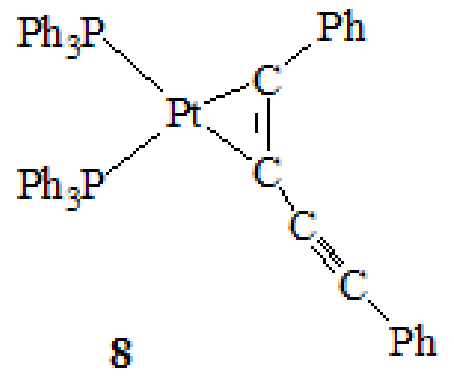

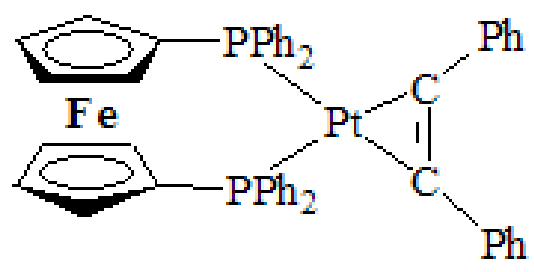

9<smiles>[18OH]P(c1ccccc1)c1cccc(P)c1P</smiles>

10

11: $10 \cdot \mathrm{C}_{6} \mathrm{H}_{6}$

12: $10 \cdot \mathrm{CH}_{2} \mathrm{Cl}_{2}$

Scheme 5 
Table 2. Comparison of bond distances $(\AA)$ and angles (deg) for complexes 5 and 6-12. ${ }^{\text {a }}$

\begin{tabular}{|c|c|c|c|c|c|c|c|c|c|c|}
\hline & \multicolumn{2}{|c|}{5} & 6 & 7 & 8 & 9 & 10 & 11 & \multicolumn{2}{|c|}{12} \\
\hline $\mathbf{P t}-\mathbf{P}$ & $2.263(3)$ & $2.260(3)$ & $2.2577(9)$ & $2.25(1)$ & $2.273(2)$ & $2.2714(16)$ & $2.2885(7)$ & $2.2820(9)$ & $2.2903(7)$ & $2.2895(7)$ \\
\hline $\mathbf{P t}-\mathbf{X}^{\mathbf{b}}$ & $2.351(3)$ & $2.340(3)$ & $2.2672(10)$ & $2.26(1)$ & $2.279(2)$ & $2.2679(18)$ & $2.2895(6)$ & $2.2910(8)$ & $2.2888(7)$ & $2.2812(7)$ \\
\hline Pt - C1 & $2.007(12)$ & $2.042(11)$ & $2.029(3)$ & $1.98(3)$ & $2.036(8)$ & $2.050(7)$ & $2.057(2)$ & $2.047(3)$ & $2.057(3)$ & $2.047(3)$ \\
\hline Pt - C2 & $2.039(11)$ & $2.073(11)$ & $2.047(3)$ & $2.02(3)$ & $2.041(7)$ & $2.040(7)$ & $2.049(2)$ & $2.048(3)$ & $2.050(3)$ & $2.048(3)$ \\
\hline C1 - C2 & $1.278(15)$ & $1.290(14)$ & $1.301(5)$ & $1.39(4)$ & $1.305(11)$ & $1.293(9)$ & $1.295(4)$ & $1.280(5)$ & $1.289(4)$ & $1.280(4)$ \\
\hline $\mathrm{C} 1-\mathrm{Pt}-\mathrm{C} 2$ & $36.8(4)$ & $36.5(4)$ & $37.24(13)$ & $39.0(11)$ & $37.3(3)$ & $36.9(2)$ & $36.77(10)$ & $36.43(13)$ & $36.58(11)$ & $36.43(11)$ \\
\hline $\mathrm{C} \alpha-\mathrm{C} 1-\mathrm{C} 2$ & $144.3(11)$ & $144.8(11)$ & $144.4(3)$ & $138.9(7)$ & $140.7(7)$ & $138.6(7)$ & $141.8(2)$ & $142.3(3)$ & $138.6(3)$ & $139.5(3)$ \\
\hline $\mathrm{C} 1-\mathrm{C} 2-\mathrm{C} \beta$ & $146.6(12)$ & $145.2(12)$ & $140.7(3)$ & $142.8(4)$ & $146.7(8)$ & $147.0(7)$ & $140.7(2)$ & $142.6(3)$ & $143.3(3)$ & $145.2(3)$ \\
\hline Ref. & & 28 & 31 & 32 & 29 & 30 & 30 & \multicolumn{2}{|c|}{30} \\
\hline
\end{tabular}

${ }^{\text {a}}$ For compounds 5 and 12, the parameters for the two independent molecules are listed in separate columns. ${ }^{b} \mathrm{X}=\mathrm{S}$ for $\mathbf{5} ; \mathrm{P}$ for $\mathbf{6 - 1 2}$. 
The structural analysis reveals the expected distorted square-planar geometry at the metal centre with the alkyne ligand in the P-Pt-S plane, the largest deviation from the PPtSC1C2 mean plane being 0.038(6) $\AA$ at C1 [0.039(6) at C3]. The elongated C1-C2 bond, $1.278(15) \AA[1.290(14)]$ and the bending of the $\mathrm{C} \equiv \mathrm{C}-\mathrm{C}$ angles $\left[144(1)^{\circ}\right.$ to $\left.147(1)^{\circ}\right]$ reflect the major contribution of $\pi^{*}$ back-donation. This bond length is quite close to those observed in the related complexes with two phosphine donors (Table 2).

\section{Conclusion}

We have presented here the first synthesis and characterization of platinum complexes of type $\mathrm{L}_{2} \mathrm{PtCl}\left(\mathrm{SnCl}_{3}\right)$ and $\mathrm{L}_{2} \mathrm{Pt}(\mathrm{PhCCPh})$ where $\mathrm{L}_{2}$ is a $\mathrm{P}, \mathrm{S}$ ligand. The study has shown that the configuration at sulphur is preserved on going from $\mathbf{1}$ to $\mathbf{2}$ and $\mathbf{5}$. It is worth noting that the synthesis of complex 1 from the corresponding ferrocene phosphine-thioether ligand and $\mathrm{PtCl}_{2}\left(\mathrm{CH}_{3} \mathrm{CN}\right)_{2}$ is also stereoselective, yielding only one of the two possible diastereoisomers. The same occurs for all other analogous $1,2-\mathrm{Fc}\left(\mathrm{PPh}_{2}\right)\left(\mathrm{CH}_{2} \mathrm{SR}\right)$ ligands with $\mathrm{R}=\mathrm{Ph}, \mathrm{Et}$, $\mathrm{tBu}$, the observed product having in all cases the sulphur atom lone pair oriented toward the unsubstituted $\mathrm{Cp}$ ring. Therefore, the planar chirality of the sulphur atom controls the configuration at the sulphur atom.

\section{Acknowledgement}

We thank the European Commission through the HYDROCHEM program (contract HPRNCT-2002-00176) for support of this work. Additional support from the CNRS is also gratefully acknowledged.

\section{Experimental part}


All reactions were carried out under dry argon by using Schlenk glassware and vacuum line techniques. Solvents were freshly distilled from standard drying agents. ${ }^{1} \mathrm{H},{ }^{13} \mathrm{C}\left\{{ }^{1} \mathrm{H},{ }^{31} \mathrm{P}\right\}$, ${ }^{119} \mathrm{Sn}\left\{{ }^{1} \mathrm{H}\right\},{ }^{31} \mathrm{P}\left\{{ }^{1} \mathrm{H}\right\},{ }^{195} \mathrm{Pt}\left\{{ }^{1} \mathrm{H}\right\}$ NMR spectra were recorded on a Bruker WMX 400 instrument operating at 400,162, 186.6, 100, and $86 \mathrm{MHz}$ respectively. Chemical shifts are reported in parts per million (ppm) relative to $\mathrm{Me}_{4} \mathrm{Si}\left({ }^{1} \mathrm{H}\right.$ and $\left.{ }^{13} \mathrm{C}\right), \mathrm{Me}_{4} \mathrm{Sn}\left({ }^{119} \mathrm{Sn}\right), 85 \% \mathrm{H}_{3} \mathrm{PO}_{4}\left({ }^{31} \mathrm{P}\right)$ or aqueous solution of $\mathrm{Na}_{2} \mathrm{PtCl}_{6}\left({ }^{195} \mathrm{Pt}\right)$. Mass spectra were obtained on a Nermag $\mathrm{R} 10-10$ instrument.

\section{Synthesis of (R/S)-(2-diphenylphosphine(phenylthiomethyl)ferrocene)chloro-}

\section{(trichlorostannyl)platinum(II), (R/S)-2.}

In a Schlenk tube under argon, $82 \mathrm{mg}(0.1 \mathrm{mmol})$ of complex $(\mathbf{R} / \mathbf{S})-\mathbf{1}$ were dissolved in $5 \mathrm{~mL}$ of distilled toluene. $\mathrm{SnCl}_{2} \cdot 2 \mathrm{H}_{2} \mathrm{O}(23 \mathrm{mg}, 0.1 \mathrm{mmol})$ were then added. The solution was refluxed for one hour, yielding a red solid in a yellow solution. The solid was filtered, washed with pentane and dried under vacuum. Yield: $93 \mathrm{mg}, 90 \% .{ }^{1} \mathrm{H}$ NMR $(500 \mathrm{MHz}$, $\left.\mathrm{CD}_{2} \mathrm{Cl}_{2}\right): \delta$ 7.69-7.56 (12H, m, Ph); 7.53-7.49 (1H, m, Ph); 7.45-7.41 (2H, m, Ph); $4.75(1 \mathrm{H}$, pseudo q, $\mathrm{J}_{\mathrm{HH}}=\mathrm{J}_{\mathrm{HP}}=1.6 \mathrm{~Hz}$, subst $\left.\mathrm{Cp}\right) ; 4.71(5 \mathrm{H}, \mathrm{s}, \mathrm{Cp}) ; 4.53\left(1 \mathrm{H}, \mathrm{dt}, \mathrm{J}_{\mathrm{HH}}=1.5 \mathrm{~Hz}, \mathrm{~J}_{\mathrm{HP}}=1\right.$ $\mathrm{Hz}$, subst Cp); $4.47\left(1 \mathrm{H}, \mathrm{d}(\mathrm{AB}), \mathrm{J}_{\mathrm{HH}}=13 \mathrm{~Hz}, \mathrm{CH}_{2}-\mathrm{Cp}\right) ; 3.69\left(1 \mathrm{H}\right.$, pseudo q, $\mathrm{J}_{\mathrm{HH}}=\mathrm{J}_{\mathrm{HP}}=1.6$ $\mathrm{Hz}$, subst $\mathrm{Cp}) ; 3.63\left(1 \mathrm{H}, \mathrm{d}(\mathrm{AB}), \mathrm{J}_{\mathrm{HH}}=13 \mathrm{~Hz}, \underline{\mathrm{C}}_{2}-\mathrm{Cp}\right) .{ }^{13} \mathrm{C}\left\{{ }^{1} \mathrm{H}\right\} \mathrm{NMR}\left(500 \mathrm{MHz}, \mathrm{CDCl}_{3}\right): \delta$ $133.9\left(\mathrm{~d}, \mathrm{~J}_{\mathrm{CP}}=12 \mathrm{~Hz}, \mathrm{PPh}_{2}\right) ; 133.2(\mathrm{~s}, \mathrm{SPh}) ; 132.9\left(\mathrm{~d}, \mathrm{~J}_{\mathrm{CP}}=12 \mathrm{~Hz}, \mathrm{PPh}_{2}\right) ; 132.8\left(\mathrm{~d}, \mathrm{~J}_{\mathrm{CP}}=3\right.$ $\left.\mathrm{Hz}, \mathrm{PPh}_{2}\right) ; 132.7\left(\mathrm{~d}, \mathrm{~J}_{\mathrm{CP}}=3 \mathrm{~Hz}, \mathrm{PPh}_{2}\right) ; 131.2(\mathrm{~s}, \mathrm{SPh}) ; 129.7\left(\mathrm{~d}, \mathrm{~J}_{\mathrm{CP}}=72 \mathrm{~Hz}\right.$, quat $\left.\mathrm{PPh}_{2}\right) ;$ $129.7(\mathrm{~s}, \mathrm{SPh}) ; 129.6\left(\mathrm{~d}, \mathrm{~J}_{\mathrm{CP}}=13 \mathrm{~Hz}, \mathrm{PPh}_{2}\right) ; 129.2$ (d, J $\left.\mathrm{J}_{\mathrm{CP}}=12 \mathrm{~Hz}, \mathrm{PPh}_{2}\right) ; 127.8(\mathrm{~s}, \mathrm{SPh}) ;$ $127.0\left(\mathrm{~d}, \mathrm{~J}_{\mathrm{CP}}=64 \mathrm{~Hz}\right.$, quat $\left.\mathrm{PPh}_{2}\right) ; 83.5\left(\mathrm{~d}, \mathrm{~J}_{\mathrm{CP}}=14 \mathrm{~Hz}\right.$, quat $\left.\mathrm{Cp}\right) ; 76.1\left(\mathrm{~d}, \mathrm{~J}_{\mathrm{CP}}=7 \mathrm{~Hz}\right.$, subst Cp); $74.7\left(\mathrm{~d}, \mathrm{~J}_{\mathrm{CP}}=7 \mathrm{~Hz}\right.$, subst Cp); $71.5(\mathrm{~s}, \mathrm{Cp}) ; 69.3\left(\mathrm{~d}, \mathrm{~J}_{\mathrm{CP}}=8 \mathrm{~Hz}\right.$, subst Cp); $65.3\left(\mathrm{~d}, \mathrm{~J}_{\mathrm{CP}}=\right.$ $73 \mathrm{~Hz}$, quat Cp); 39.5 (s, $\left.\underline{\mathrm{CH}}_{2}-\mathrm{Cp}\right) .{ }^{31} \mathrm{P} \mathrm{NMR}\left(500 \mathrm{MHz}, \mathrm{CDCl}_{3}\right): \delta 1.21\left(\mathrm{~J}_{\mathrm{PPt}}=3517 \mathrm{~Hz}, \mathrm{~J}_{\mathrm{PSn}}\right.$ 
$=183 \mathrm{~Hz}) .{ }^{195} \mathrm{Pt}$ NMR $\left(500 \mathrm{MHz}, \mathrm{CDCl}_{3}\right): \delta-4273 .{ }^{119} \mathrm{Sn}$ NMR $\left(500 \mathrm{MHz}, \mathrm{CDCl}_{3}\right): \delta-263.4$.

MS (DCI; $\left.\mathrm{NH}_{3}\right): \mathrm{m} / \mathrm{z}=966\left(\mathrm{M}+\mathrm{NH}_{3} .8 \%\right) ; 776\left(\mathrm{M}-\mathrm{SnCl}_{2}+\mathrm{NH}_{4} .51 \%\right)$.

Synthesis of (R/S)-(2-diphenylphosphino-(phenylthiomethyl)ferrocene)(diphenylacetylene)platinum(0), (R/S)-5. In a Schlenk tube under argon, $80 \mathrm{mg}(0.1 \mathrm{mmol})$ of complex (R/S)-1 and $18 \mathrm{mg}(0.1 \mathrm{mmol})$ of diphenylacetylene were dissolved in $5 \mathrm{~mL}$ of dry THF. A solution of $\mathrm{NaBH}(\mathrm{OMe})_{3}(78 \mathrm{mg}, 0.6 \mathrm{mmol})$ in $3 \mathrm{ml}$ of dry THF was then added. The solution was stirred for two hours at room temperature. A small amount of white solid that had formed in the brown solution was eliminated by filtration. The solvent was then evaporated to dryness yielding the product as a red-brown solid. The solid was washed with pentane and dried under vacuum to yield a red solid (77 mg, 89\% yield). ${ }^{1} \mathrm{H}$ NMR (500 MHz, $\left.\mathrm{CDCl}_{3}\right): \delta$ 7.91-7.85 (3H, m, Ph); 7.73-7.63 (2H, m, Ph); 7.57-7.46 (3H, m, Ph); 7.42-7.21 $(12 \mathrm{H}, \mathrm{m}, \mathrm{Ph}) ; 7.14-6.98(5 \mathrm{H}, \mathrm{m}, \mathrm{Ph}) ; 4.50\left(1 \mathrm{H}\right.$, pseudo $\mathrm{q}, \mathrm{J}_{\mathrm{HH}}=\mathrm{J}_{\mathrm{HP}}=2 \mathrm{~Hz}$, subst Cp $) ; 4.44$ $\left(1 \mathrm{H}, \mathrm{d}(\mathrm{AB}), \mathrm{J}_{\mathrm{HH}}=12 \mathrm{~Hz}, \mathrm{C}_{2}-\mathrm{Cp}\right) ; 4.38(5 \mathrm{H}, \mathrm{s}, \mathrm{Cp}) ; 4.31\left(1 \mathrm{H}, \mathrm{t}, \mathrm{J}_{\mathrm{HH}}=2 \mathrm{~Hz}\right.$, subst $\left.\mathrm{Cp}\right) ; 3.93$ $\left(1 \mathrm{H}, \mathrm{d}, \mathrm{J}_{\mathrm{HH}}=2 \mathrm{~Hz}\right.$, subst $\left.\mathrm{Cp}\right) ; 3.62\left(1 \mathrm{H}, \mathrm{d}(\mathrm{AB}), \mathrm{J}_{\mathrm{HH}}=12 \mathrm{~Hz}, \mathrm{C}_{2}-\mathrm{Cp}\right) .{ }^{13} \mathrm{C}\left\{{ }^{1} \mathrm{H}\right\} \mathrm{NMR}(500$ $\left.\mathrm{MHz}, \mathrm{CDCl}_{3}\right): \delta 137.0\left(\mathrm{~d}, \mathrm{~J}_{\mathrm{CP}}=4 \mathrm{~Hz}\right.$, quat $\left.\mathrm{SPh}\right) ; 136.5\left(\mathrm{~d}, \mathrm{~J}_{\mathrm{CP}}=42 \mathrm{~Hz}\right.$, quat $\left.\mathrm{PPh}_{2}\right) ; 134.3(\mathrm{~d}$, $\mathrm{J}_{\mathrm{CP}}=15 \mathrm{~Hz}$, o $\left.\mathrm{PPh}_{2}\right) ; 133.8\left(\mathrm{~d}, \mathrm{~J}_{\mathrm{CP}}=47 \mathrm{~Hz}\right.$, quat $\left.\mathrm{PPh}_{2}\right) ; 133.4\left(\mathrm{~d}, \mathrm{~J}_{\mathrm{CP}}=15 \mathrm{~Hz}, \mathrm{o} \mathrm{PPh}_{2}\right) ; 132.9$ $(\mathrm{s}, \mathrm{SPh}) ; 132.6(\mathrm{~s}, \mathrm{SPh}) ; 129.9(\mathrm{~s}, \underline{\mathrm{PhC}} \equiv \mathrm{CPh}) ; 129.8\left(\mathrm{~d}, \mathrm{~J}_{\mathrm{CP}}=2.5 \mathrm{~Hz}, \mathrm{p} \mathrm{PPh}\right) ; 129.3\left(\mathrm{~d}, \mathrm{~J}_{\mathrm{CP}}=\right.$ 2.5Hz, p $\left.\mathrm{PPh}_{2}\right) ; 129.2(\mathrm{~s}, \mathrm{SPh}) ; 128.9$ (s, quat $\left.\underline{\mathrm{PhC}} \equiv \mathrm{CPh}\right) ; 128.6(\mathrm{~s}, \underline{\mathrm{PhC}} \equiv \mathrm{CPh}) ; 128.4$ (s, quat $\underline{\mathrm{PhC}} \equiv \mathrm{CPh}) ; 128.3\left(\mathrm{~d}, \mathrm{~J}_{\mathrm{CP}}=10 \mathrm{~Hz}, \mathrm{~m} \mathrm{PPh}\right) ; 128.2(\mathrm{~s}, \mathrm{SPh}) ; 127.7(\mathrm{~s}, \underline{\mathrm{PhC}} \equiv \mathrm{CPh}) ; 127.7(\mathrm{~s}$, $\underline{\mathrm{PhC}} \equiv \mathrm{CPh}) ; 127.6\left(\mathrm{~d}, \mathrm{~J}_{\mathrm{CP}}=10 \mathrm{~Hz}, \mathrm{~m} \mathrm{PPh} 2\right) ; 127.1(\mathrm{~s}, \mathrm{PhC} \equiv \mathrm{CPh}) ; 126.5(\mathrm{~s}, \mathrm{PhC} \equiv \mathrm{CPh}) ; 125.8$ $(\mathrm{s}, \underline{\mathrm{Ph}} \equiv \mathrm{CPh}) ; 125.4(\mathrm{~s}, \underline{\mathrm{PhC}} \equiv \mathrm{CPh}) ; 87.4\left(\mathrm{~d}, \mathrm{~J}_{\mathrm{CP}}=18 \mathrm{~Hz}\right.$, quat $\left.\mathrm{Cp}\right) ; 74.6\left(1 \mathrm{C}, \mathrm{d}, \mathrm{J}_{\mathrm{CP}}=6 \mathrm{~Hz}\right.$, subst $\mathrm{Cp}) ; 73.4\left(\mathrm{~d}, \mathrm{~J}_{\mathrm{CP}}=28 \mathrm{~Hz}\right.$, quat $\left.\mathrm{Cp}\right) ; 73.2(\mathrm{~s}$, subst $\mathrm{Cp}) ; 70.7(\mathrm{~s}, \mathrm{Cp}) ; 66.8\left(1 \mathrm{C}, \mathrm{d}, \mathrm{J}_{\mathrm{CP}}=\right.$ 5Hz, subst Cp); $42.3\left(\mathrm{~d}, \mathrm{~J}_{\mathrm{CP}}=7 \mathrm{~Hz}, \underline{\mathrm{CH}}_{2} \mathrm{Cp}\right) .{ }^{31} \mathrm{P} \mathrm{NMR}\left(500 \mathrm{MHz}, \mathrm{CDCl}_{3}\right): \delta 12.6\left(\mathrm{~J}_{\mathrm{PPt}}=\right.$ $3758 \mathrm{~Hz})$. 
X-ray crystallography. A single crystal of each compound was mounted under inert perfluoropolyether at the tip of a glass fibre and cooled in the cryostream of an OxfordDiffraction XCALIBUR CCD diffractometer. Data were collected using the monochromatic MoK $\alpha$ radiation $(\lambda=0.71073)$. The structures were solved by direct methods $\left(\right.$ SIR97) ${ }^{33}$ and refined by least-squares procedures on $F^{2}$ using SHELXL-97. ${ }^{34}$ All $\mathrm{H}$ atoms attached to carbon were introduced in idealised positions and treated as riding on their parent atoms in the calculations. The drawing of the molecules was realised with the help of ORTEP3. ${ }^{35}$ Crystal data and refinement parameters are shown in Table 3. Bond distances and angles are given in Tables 1 and 2 .

Crystallographic data (excluding structure factors) have been deposited with the Cambridge Crystallographic Data Centre as supplementary publication no. CCDC 675787 \& 675788. Copies of the data can be obtained free of charge on application to the Director, CCDC, 12 Union Road, Cambridge CB2 1EZ, UK (fax: (+44) 1223-336-033; e-mail: deposit@ccdc.cam.ac.uk).

Table 3. Crystal data and structure refinement

\begin{tabular}{|l|l|l|}
\hline Identification code & \multicolumn{1}{|c|}{$(\mathbf{R} / \mathbf{S})-2$} & \multicolumn{1}{c|}{$(\mathbf{R} / \mathbf{S})-5$} \\
\hline Empirical formula & $\mathrm{C}_{59} \mathrm{H}_{52} \mathrm{Cl}_{10} \mathrm{Fe}_{2} \mathrm{P}_{2} \mathrm{Pt}_{2} \mathrm{~S}_{2} \mathrm{Sn}_{2}$ & $\mathrm{C}_{43} \mathrm{H}_{35} \mathrm{C}_{10} \mathrm{FePPtS}$ \\
\hline Formula weight & 990.41 & 865.68 \\
\hline Temperature,K & $180(2)$ & $180(2) \mathrm{K}$ \\
\hline Crystal system & Monoclinic & Triclinic \\
\hline Space group & $\mathrm{P} 2{ }_{1} / \mathrm{c}$ & $\mathrm{P}-1$ \\
\hline $\mathrm{a}, \AA$ & $10.4191(5)$ & $12.9671(19)$ \\
\hline $\mathrm{b}, \AA$ & $17.8962(9)$ & $16.1949(19)$ \\
\hline $\mathrm{c}, \AA$ & $35.1630(17)$ & $18.672(2)$ \\
\hline$\alpha,{ }^{\circ}$ & 90.0 & $96.936(9)$ \\
\hline$\beta,^{\circ}$ & $93.004(4)$ & $103.775(11)$ \\
\hline$\gamma^{\circ}$ & 90.0 & $100.870(11)$ \\
\hline $\mathrm{V}, \AA^{3}$ & $6547.6(6)$ & $3683.2(8)$ \\
\hline
\end{tabular}




\begin{tabular}{|c|c|c|}
\hline $\mathrm{Z}$ & 8 & 4 \\
\hline Dcalc, $\mathrm{Mg} / \mathrm{m}^{3}$ & 2.009 & 1.561 \\
\hline$\mu, \mathrm{mm}-1$ & 5.998 & 4.317 \\
\hline $\mathrm{F}(000)$ & 3784 & 1712 \\
\hline Crystal size, mm3 & $0.27 \times 0.041 \times 0.039$ & $0.33 \times 0.16 \times 0.15$ \\
\hline$\theta^{\circ}$, range & 3.00 to 25.68 & 2.82 to 26.37 \\
\hline Reflections collected & 44982 & 28106 \\
\hline Unique reflections [Rint] & $12418[0.0796]$ & $15016[0.0865]$ \\
\hline Obsd reflections $[\mathrm{I}>2 \sigma(\mathrm{I})]$ & 7133 & 7907 \\
\hline Completness & 99.8 & 99.7 \\
\hline Absorption correction & Multi-scan & Multi-scan \\
\hline $\mathrm{T}_{\min } / T_{\max }$ & $0.3745 / 0.7984$ & $0.1588 / 0.3062$ \\
\hline parameters & 712 & 869 \\
\hline GOF on $\mathrm{F}^{2}$ & 0.814 & 0.901 \\
\hline $\mathrm{R} 1, \mathrm{wR} 2[\mathrm{I}>2 \sigma(\mathrm{I})]$ & $0.0440,0.0445$ & $0.0634,0.1442$ \\
\hline R1, wR2 (all data) & $0.0971,0.0527$ & $0.1034,0.1618$ \\
\hline$\Delta \rho_{\min }, \Delta \rho_{\max }\left(\mathrm{e} \AA^{-3}\right)$ & $-0.999,1.310$ & $-2.581,2.817$ \\
\hline
\end{tabular}


1 (a) T. J. Kealy, P. L. Pauson, Nature 168 (1951) 1039. (b) P. L. Pauson, J. Organomet. Chem. 637-639 (2001) 3.

2 (a) F. A. Cotton, G. Wilkinson, J. Am. Chem. Soc. 74 (1952) 5764. (b) F. A. Cotton, J. Organomet. Chem. 637 (2001) 18.

3 F. Barrière, Encyclopedia of Electrochemistry 7a (2006) 461.

4 (a) A. Federman Neto, A. C. Pelegrino, V. A. Darin, Trends in Organometallic Chemistry 4 (2002) 147. (b) T. Chuard, R. Deschenaux, Chimia 57 (2003) 597. (c) J. J. Wang, L. Wang, W. Q. Wang, T. Chen, Journal of Polymer Materials 22 (2005) 169.

5 (a) C. J. Richards, A. J. Locke, Tetrahedron Asymmetry, 9 (1998) 2377. (b) G. G. A. Balavoine, J.-C. Daran, G. Iftime, E. Manoury, C. Moreau-Bossuet, J. Organomet. Chem. 567 (1998) 191. (c) O. Riant, H. B. Kagan, Advances in Asymmetric Synthesis, A. Hassner Ed; Jai press, 2 (1997) 189. (d) A. Togni, Angew. Chem. Int. Ed. 35 (1996) 1475.

6 (a) R. Gomez Arrayas, J. Adrio, J. C. Carretero, Angew. Chem. Int. Ed. 45 (2006) 7674. (b) R. C. J. Atkinson, V. C. Gibson, N. J. Long, Chem. Soc. Rev. 33 (2004) 313. (c) T. J. Colacot, Chem. Rev. 103 (2003) 3101.

(a) M. Sawamura, Y. Nakayama, T. Kato, Y. Ito, J. Org. Chem. 60 (1995) 1727. (b) M. Sawamura, M. Sudoh, Y. Ito, J. Am. Chem. Soc. 118 (1996) 3309. (c) R. Kuwano, H. Miyazaki, Y. Ito, Chem. Commun. (1998) 71. (d) R. Kuwano, T. Uemura, M. Saitoh, Y. Ito, Tetrahedron Lett. 40 (1999) 1327. (e) R. Kuwano, K. Sato, T. Kurokawa, D. Karube, Y. Ito, J. Am. Chem. Soc. 122 (2000) 7614.

8 H.-U. Blaser, W. Brieden, B. Pugin, F. Spindler, M. Studer, A. Togni, Topics in Catalysis 19 (2002) 3.

$9 \quad$ H.-U. Blaser, Adv. Synth. Catal. 344 (2002) 17.

(a) T. Ireland, G. Grossheimann, C. Wieser-Jeunesse, P. Knochel, Angew. Chem., Int. Ed. Engl. 38 (1999) 3212. (b) M. Lotz, K. Polborn, P. Knochel, Angew. Chem., Int. Ed. Engl. 41 (2002) 4708. (c) F. Spindler, C. Malan, M. Lotz, M. Kesselgruber, U. 
Pittelkow, A. Rivas-Nass, O. Briel, H. U. Blaser, Tetrahedron-Asymmetry 15 (2004) 2299.

T. Sturm, W. Weissensteiner, F. Spindler, Adv. Synth. Catal. 345 (2003) 160.

H. A. McManus, P. J. Guiry, Chem. Rev. 104 (2004), 4151.

O. B. Sutcliffe, M. R. Bryce, Tetrahedron Asymmetry 14 (2003) 2297.

S. Cabrera, O. G. Mancheno, R. G. Arrayas, I. Alonso, P. Mauleon, J. C. Carretero, Pure Appl. Chem. 78 (2006) 257.

L. Routaboul, S. Vincendeau, J.-C. Daran, E. Manoury, Tetrahedron Asymmetry 16 (2005) 2685.

N. Mateus, L. Routaboul, J.-C. Daran, E. Manoury, J. Organomet. Chem. 691 (2006) 2297.

(a) R. Malacea, E. Manoury, L. Routaboul, J.-C. Daran, R. Poli, J. P. Dunne, A. C. Withwood, C. Godard, S. B. Duckett, Eur. J. Inorg. Chem. (2006) 1803. (b) R. Malacea, J.-C. Daran, S. B. Duckett, J. P. Dunne, C. Godard, E. Manoury, R. Poli, A. C. Whitwood, Dalton Trans. (2006) 3350. (c) R. Malacea, L. Routaboul, E. Manoury, J.-C. Daran, R. Poli, J. Organomet. Chem., in press (DOI: 10.1016.jorganchem.2007.08.021).

L. Routaboul, S. Vincendeau, C. O. Turrin, A. M. Caminade, J. P. Majoral, J. C. Daran, E. Manoury, J. Organomet. Chem. 692 (2007) 1064.

E. Le Roux, R. Malacea, E. Manoury, R. Poli, L. Gonsalvi, M. Peruzzini, Adv. Synth. Catal. 349 (2007) 309.

Selected references : (a) R. van Duren, J. I. van der Vlugt, H. Kooijman, A. L. Spek, D. Vogt, Dalton Trans. (1991) 1053-1059. (b) G. Petocz, Z. Berente, T. Kegl, L. Kollar, J. Organomet. Chem., 689 (2004) 1888-1193. (c) P. Meesen, D. Vogt, W. Keim, J. Organomet. Chem., 551 (1998) 165-170.

F. Agbossou, J.-F. Carpentier, A. Mortreux, Chem. Rev. 95(1995), 2485-506.

Selected references : (a) R. van Duren, L. J. M. Cornelissen, J. I. van der Vlugt, J. P. J. Huijbers, A. M. Mills, A. L. Spek, C. Müller, D. Vogt, Helv. Chim. Act. 89 (2006) 1547-1558. (b) C. Hegedus, J. Madarsz, H. Gulyas, A. Szollosy, J. Bakos, Tetrahedron: Asym., 12 (2001) 2867-2873. (c) C. P. Casey, S. C. Martins, M. A. Fagan, J. Am. Chem. Soc., 126 (2004) 5585

(a) G. Parrinello, J. K. Stille, J. Am. Chem. Soc. 109 (1987) 7122. (b) L. Dahlenburg, S. Mertel, J. Organomet. Chem. 689 (2004) 1888. 
For reviews about ${ }^{195} \mathrm{Pt}$ NMR, see: (a) P. S. Pregosin, Coor. Chem. Rev. 44 (1982) 247. (b) J. R. L. Priqueler, I. S. Butler, F. D. Rochon, Appl. Spectr. Rev. 41 (2006) 185. (c) B. M. Still, P. G. Anil Kumar, J. R. Aldrich-Wright, W. S. Price, Chem. Soc. Rev. 36 (2007) 665.

P. S. Pregosin, S. N. Sze, Helv. Chim. Acta. 61 (1978) 1848.

(a) M. L. Clarke, Polyhedron 20 (2001) 151-164. (b) T. Ishiyama, N. Miyaura, The Chemical Record 3 (2004) 271. (c) H.-U. Blaser, M. Studer, Acc. Chem. Res. 40 (2007) 1348.

I. Kovacik, D. K. Wicht, N. S. Grewal, D. S. Glueck, C. D. Incarvito, I. A. Guzei, A.

L. Rheingold, Organometallics 19 (2000) 950.

C. Muller, R. J. Lachicotte, W. D. Jones, Organometallics 21 (2000) 1118.

C. V. Ursini, G. H. M. Dias, M. Hörner, A. J. Bortoluzzi, M. K. Morigaki, Polyhedron 19(2000) 2261.

K. J. Harris, G. M. Bernard, C. McDonald, R. McDonald, M. J. Ferguson, R. E. Wasylishen, Inorg. Chem. 25(2006) 2461.

S. Yamazaki, Z. Taira, T. Yonemura, A. J. Deeming, Organometallics 24 (2005) 20.

S. Yamazaki, A. J. Deeming, D. M. Speel, Organometallics 17 (1998) 775.
A. Altomare, M. C. Burla, M. Camalli, G. L. Cascarano, C. Giacovazzo, A. Guagliardi, A. G. G. Moliterni, G. Polidori, R. Spagna, (1999) SIR97- a program for automatic solution of crystal structures by direct methods. J. Appl. Cryst. 32, 115.

G. M. Sheldrick, (1997) SHELXL97. Program for crystal structure refinement. University of Göttingen, Germany. 